\title{
Selección de genes de referencia en semen equino criopreservado para su uso en estudios de expresión genética con la técnica de PCR cuantitativa
}

\author{
Pérez Rico A. ${ }^{1}$, Crespo Castejón F. ${ }^{2}$, Sanmartín Sánchez L. ${ }^{1}$, Miró Arias Ma . ${ }^{3}$, Vega Pla JL. ${ }^{4}$ \\ Sanid. mil. 2014; 70 (1): 20-29; ISSN: 1887-8571
}

\begin{abstract}
RESUMEN
Introducción: La gestión de bancos de germoplasma implica la conservación y uso de dosis seminales, pero también pueden ser una fuente de estudio sobre la calidad de los sementales y las propiedades del semen para su empleo post descongelación. Un criterio para medir la calidad seminal puede basarse en las diferencias de expresión de algunos genes implicados en la espermatogénesis y la maduración espermática. Objetivo: Análisis de genes expresados en semen equino criopreservado que ofrezcan una adecuada amplificación, especificidad y estabilidad para su empleo como genes de referencia en futuros estudios de expresión genética. Material y métodos: Purificación de espermatozoides vivos mediante un gradiente de concentración discontinua a partir de pajuelas de semen criopreservado correspondiente a cuatro sementales. Extracción orgánica de ácidos ribonucleicos con tratamiento con la enzima desoxiribonucleasa y la amplificación selectiva de siete genes candidatos mediante retrotranscripción y reacción en cadena de la polimerasa en tiempo real en un solo paso. Resultados: Tres de los genes seleccionados, $\beta$-Actina, Ubiquitina B y proteína Ribosomal L32 se amplifican correctamente. $\beta$-Actina, Ubiquitina $B$ manifiestan la mayor estabilidad. Conclusión: En los espermatozoides procedentes de muestras de semen criopreservado equino se puede detectar la presencia de ARNm, siendo el gen de la $\beta$-Actina y de la Ubiquitina $B$ los más indicados como genes de referencia de los siete candidatos analizados.
\end{abstract}

PALABRAS CLAVE: ARN mensajero, genes de referencia, semen equino criocongelado.

Reference genes selection in cryopreserved equine semen for its use in studies of gene expression with the quantitative PCR technique SUMMARY: Introduction: The germoplasm bank management involves the conservation and use of semen doses, but can also be a source of study on the quality of stallions and semen properties for use after thawing. A criterion for measuring the semen quality may be based on differences in expression of some genes involved in spermatogenesis and sperm maturation. Objective: Analysis of genes expressed in equine cryopreserved sperm that can provide adequate amplification, specificity and stability for use as future reference genes in gene expression studies. Material and methods: Purification of live sperm through a discontinuous concentration gradient from cryopreserved semen straws corresponding to four stallions. Organic extraction of ribonucleic acids with deoxyribonuclease treatment and the selective amplification of seven candidate genes using a retrotranscription and a real time chain reaction of the polymerase in one step mode. Specificity is tested by melting curves and agarose gel electrophoresis. Also the stability of the genes is calculated. Results: Three of the selected genes, $\beta$-actin, Ubiquitin B and Ribosomal protein L32 were properly amplified. $\beta$-Actin and Ubiquitin $B$ showed the best stability. Conclusion: mRNA was amplified from equine cryopreserved semen samples, being the $\beta$-Actin and the Ubiquitin $B$ genes the most suitable reference genes of the seven candidates analyzed.

KEY WORDS: Messenger RNA, Reference genes, Equine cryopreserved sperm.

\section{INTRODUCCIÓN}

Los bancos de germoplasma pueden ser una fuente de muestras de semen criopreservado para la investigación de genes implicados en diferentes aspectos relacionados con la calidad seminal y fertilidad del semental. Es admitido que el ácido ri-

${ }^{1}$ Tte. Veterinario Laboratorio de Investigación Aplicada. Cría Caballar de las Fuerzas Armadas. Córdoba. España.

${ }^{2}$ Tcol. Veterinario. Centro Militar de Cría Caballar de Ávila. Cría Caballar de las Fuerzas Armadas. Ávila. España.

${ }^{3}$ Veterinaria. Departamento de Genética. Universidad de Córdoba. España.

${ }^{4}$ Tcol. Veterinario. Laboratorio de Investigación Aplicada. Cría Caballar de las Fuerzas Armadas. Córdoba. España.

Dirección para correspondencia: Jose Luis Vega Pla. Laboratorio de Investigación Aplicada, Apartado de Correos 2087, 14080-Córdoba. Telf.: 957325312 Fax.: 957322493. Correo: jvegpla@oc.mde.es.

Recibido: 25 de abril de 2013

Aceptado: 18 de octubre de 2013 bonucleico mensajero (ARNm) se degrada a gran velocidad una vez que la célula entra en un proceso de apoptosis que termina con la muerte. Los espermatozoides descongelados apenas se mantienen vivos unas horas por lo que se deduce que los procesos de apoptosis ya se han iniciado y como consecuencia, las cantidades de ARNm también disminuyen rápidamente. En el caso del caballo esto se agrava considerablemente, prueba de ello es la enorme dificultad descrita en los primeros trabajos publicados sobre ARNm de espermatozoides, donde se observa que los protocolos de extracción de ARN en semen humano no rinden de igual manera que en caballos ${ }^{1}$. Además, existen diferencias entre especies que requieren ajustes para optimizar los protocolos de aislamiento de ARN a partir de esperma ${ }^{2}$.

Los estudios de expresión genética consisten en analizar la síntesis de ARNm de una serie de genes en una situación concreta de actividad celular. El ARNm de los espermatozoides apenas se traduce en proteínas, por lo que se pensaba que los perfiles de ARNm de los espermatozoides eran un reflejo de la actividad 


\section{Selección de genes de referencia en semen equino criopreservado para su uso en estudios de ...}

de sus precursores, las espermatogonias 3 ; no obstante, un estudio de Gur y Breitbart ${ }^{4}$ en 2006 demuestran la incorporación de aminoácidos marcados en polipéptidos durante la capacitación espermática, por lo que hay cierta actividad de traducción genética. Por otro lado, estudios preliminares en el hombre ${ }^{5}$ han mostrado un patrón de expresión genómica alterado en los espermatozoides de individuos infértiles. Estos resultados indican que la transcripción de determinados genes se puede ocasionar sin que se produzca obligatoriamente una traducción de los mismos en proteínas. Esta actividad de transcripción del ADN en ARN se puede estudiar en condiciones diferentes, lo que permitiría profundizar en los mecanismos implicados en la fertilidad, así como una herramienta útil en el ámbito de la reproducción equina para la selección de sementales.

Los estudios de expresión genética mediante PCR en tiempo real o PCR cuantitativa (qPCR) requieren de unos genes que se usan como calibradores. Se trata de genes que se expresan de forma constante e independiente del estado fisiológico de la célula. A estos genes se les denomina genes de referencia. Por lo tanto, el primer paso antes de abordar estudios más específicos de expresión genética, es la identificación y caracterización de genes de referencia. La elección correcta de los genes de referencia para la normalización de la técnica de PCR cuantitativa resulta esencial para reflejar datos fiables sobre los procesos biológicos de las proteínas objeto de estudio ${ }^{6}$. Además, se ha demostrado que el uso de un solo gen de referencia es susceptible de inducir a errores en la interpretación de los resultados de la PCR en tiempo real ${ }^{7}$. En consecuencia, para normalizar las expresiones de genes cuando se trabaja con PCR en tiempo real, es conveniente utilizar más de un gen de referencia, sobre todo cuando no se puede encontrar un único gen con características óptimas para realizar una cuantificación relativa de la expresión de otros genes ${ }^{6,8}$. A estas dificultades se suman, por un lado la labilidad intrínseca del semen equino, y por otro los efectos dañinos de la congelación sobre estas células.

El objetivo del presente estudio es determinar la estabilidad de la expresión de distintos genes para su empleo como genes de referencia en futuros estudios de expresión genética en semen criopreservado.

\section{MATERIAL Y MÉTODOS}

Las muestras de semen utilizadas proceden de cuatro sementales adultos sanos. La extracción del semen se realiza con vagina artificial, con posterior dilución en soluciones de crioconservación y envasado en pajuelas de $500 \mathrm{uL}$ de acuerdo a métodos convencionales. Se determina el porcentaje de fragmentación de la cromatina usando el kit comercial Sperm-Halomax ${ }^{\circledR}$ (HALOTECH DNA SL.)

Las dosis seminales se han mantenido en congelación con nitrógeno líquido durante un periodo superior a 24 meses. El proceso de descongelación se realiza en un baño termostático a $37^{\circ} \mathrm{C}$ durante 30 segundos. Las muestras se centrifugan en gradiente de densidad discontinuo a través de la solución Top Layer (Equipure ${ }^{\circledR}$ ) que contiene un $40 \%$ de partículas de sílice silanizado para separar los espermatozoides vivos de muertos y las células somáticas.
Se diluye la muestra hasta obtener una cantidad de unos cinco millones de células. Se realiza una extracción orgánica del ARN (TRIsure $^{\mathrm{TM}}$ de Bioline).y purificación con columna de silicagel (Direct-zol ${ }^{\mathrm{TM}}$ RNA MiniPrep de Zymo ResEARCH) seguida de una digestión del ADN residual con Dnase I (SigmA). Se cuantifican las muestras en un espectrofotómetro GeneQuant (PHARmACIA). Las muestras de ARN extraídas antes y después de la digestión del ADN se someten, junto con una muestra de ADN control, a una qPCR para amplificar una secuencia del gen de la Interleukina 2 (IL-2) con el objetivo de detectar la posible presencia de ADN genómico en el ARN después de la extracción, el ADNm de la $I L-2$ tiene un tamaño de $117 \mathrm{pb}$ y el ADN genómico de $208 \mathrm{pb}$ debido a un intron de la secuencia que no se transcribe. Se amplifican 50 ng de muestra usando la enzima MyTaq HS (Bioline) con una concentración final de cebadores (tabla1) de $0,3 \mathrm{mM}$, se incorpora Evagreen ${ }^{\circledR}$ (Bıттіuм INC.) como intercalante. Se emplea un termociclador RotorGene 6000 (CORBETT), con una primera etapa de activación de la polimerasa de $1 \mathrm{~min}$. a $95^{\circ} \mathrm{C}$, y de amplificación de 45 ciclos de $95^{\circ} \mathrm{C}-15 \mathrm{seg}, 55^{\circ} \mathrm{C}-20 \mathrm{seg}$ y $72^{\circ} \mathrm{C}-20 \mathrm{seg}$. La detección de fluorescencia se hace durante la fase de síntesis de $\operatorname{ADN}\left(72^{\circ} \mathrm{C}\right)$ de cada ciclo. El uso de muchos ciclos en qPCR es habitual para comprobar que la reacción de control sin muestra no amplifica inespecíficamente o lo hace muy tarde.

Se han seleccionado siete genes candidatos utilizados comúnmente como genes de referencia en estudios de expresión génica (tabla 1). Cuando ha sido necesario, se ha usado la aplicación informática Primer3 Plus ${ }^{9}$ para el diseño de los cebadores. Se lleva a cabo la retrotranscripción y amplificación con cebadores específicos (RT-qPCR) en un solo paso (One-Step RT-PCR PreMix Kit de Intron Biotechnology) a partir de $50 \mathrm{ng}$ del ARN obtenido de las muestras de semen. Como control de la qPCR se procesan también tres diluciones decimales de ARNm de leucocitos de un caballo obtenido con el mismo procedimiento. Se

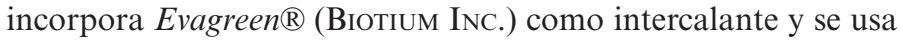
una concentración final de cebadores de $0,6 \mathrm{uM}$. Se realizan las reacciones en el termociclador con una primera etapa de $45^{\circ} \mathrm{C}-$ 30 min para realizar la retrotranscripción, seguida de una fase de activación de la polimerasa de $5 \mathrm{~min}$ a $95^{\circ} \mathrm{C}$ y de amplificación de 45 ciclos de $95^{\circ} \mathrm{C}-15 \mathrm{seg}, 55^{\circ} \mathrm{C}-20 \mathrm{seg}$ y $72^{\circ} \mathrm{C}-20 \mathrm{seg}$. La detección de fluorescencia se hace durante la fase de síntesis. A continuación, se lleva a cabo un incremento de temperatura de $65^{\circ} \mathrm{C}$ a $95^{\circ} \mathrm{C}$ en etapas de $0,5^{\circ} \mathrm{C}-5$ seg con el fin de detectar la temperatura a la que las secuencias amplificadas se disocian en cadenas simples. Se realiza un análisis de la curva de fusión con el módulo Melt Curve analysis del programa Rotor-Gene 6000 software y una electroforesis en gel de agarosa al 3\% para comprobar la especificidad de la reacción.

Se determina el ciclo de cuantificación $(\mathrm{Cq})$ como el primer punto detectado a un $80 \%$ por debajo del nivel máximo de amplificación exponencial obtenido al aplicar un cálculo de la segunda derivativa de la curva mediante el módulo de análisis Comparative Quantitation del Rotor-Gene 6000 software (CoRBETT). Con el mismo programa se calcula también la eficiencia de la amplificación de cada muestra.

Los promedios de los valores de Cq para cada duplicado de las muestras se analizan tanto en el software NormFinder ${ }^{10}$ como en el software Rest $2009^{11}$ para realizar los cálculos de estabilidad de los diferentes genes de referencia candidatos. 


\section{A. Pérez Rico, et al.}

Tabla 1. Secuencias de los cebadores empleados para amplificar parte de siete genes candidatos y el gen de la Interleukina 2.

\begin{tabular}{|c|c|c|c|c|c|}
\hline Gen & Denominación & Clave GeneBank & Cebadores 5' $\rightarrow 3^{\prime}$ & Tamaño (pb) & Ref. \\
\hline$A C T B$ & $\beta$-Actina & AF035774 & $\begin{array}{l}\text { CCAGCACGATGAAGATCAAG } \\
\text { GTGGACAATGAGGCCAGAAT }\end{array}$ & 88 & (Smits et al. 2009) \\
\hline$A T P 5 B$ & $A T P$ sintasa subunidad $B$ & NM_001195525.1 & $\begin{array}{l}\text { TGGGGTGCAAAAGATCCTAC } \\
\text { AAATGGCCTGTGAACAACTC }\end{array}$ & 168 & Este trabajo \\
\hline$G A P D H$ & $\begin{array}{l}\text { Gliceraldehido-3P- } \\
\text { dehidrogenasa }\end{array}$ & AF083897 & $\begin{array}{l}\text { GGTGAAGGTCGGAGTAAACG } \\
\text { AATGAAGGGGTCATTGATGG }\end{array}$ & 106 & (Beekman et al. 2011) \\
\hline HSP9O & $\begin{array}{l}\text { Proteina de choque } \\
\text { térmico }\end{array}$ & NM_001163955.1 & $\begin{array}{l}\text { AGCAAGGCCAAGTTTGAGAA } \\
\text { ATTGTGGAGTTGTCCCGAAG }\end{array}$ & 185 & Este trabajo \\
\hline$I L 2$ & Interleukina 2 & EU438768.1 & $\begin{array}{l}\text { GGGAAACACAGCAACAACTG } \\
\text { GCCTTCTTGGGCATGTTAAT }\end{array}$ & 127 & Este trabajo \\
\hline RPL32 & Proteína ribosomal L32 & XM_001492042.2 & $\begin{array}{c}\text { GGGAGCAATAAGAAAACGAAGC } \\
\text { CTTGGAGGAGACATTGTGAGC }\end{array}$ & 138 & (Beekman et al. 2011) \\
\hline$S D H A$ & Succinato deshidrogenasa & XM_001490889.3 & $\begin{array}{l}\text { TCCATCGCATAAGAGCAAAG } \\
\text { GGTGGAACTGAACGAACTCC }\end{array}$ & 159 & Este trabajo \\
\hline$U B B$ & Ubiquitina $B$ & AF506969 & $\begin{array}{l}\text { TTCGTGAAGACCCTGACC } \\
\text { CCTTATCCTGGATCTTGGC }\end{array}$ & 91 & (Beekman et al. 2011) \\
\hline
\end{tabular}

\section{RESULTADOS}

Las muestras de los animales 1 y 2 , poseen una fragmentación a las 24 horas relativamente baja (18\% y $38 \%$ respectivamente) y constituyen el grupo de control mientras que las muestras 3 y 4 , que poseen un $100 \%$ de fragmentación, constituyendo el grupo afectado.

El proceso de extracción de ARN no es totalmente eficaz para la eliminación de $\mathrm{ADN}$ si no se acompaña de una digestión específica de éste. Prueba de ello, es que las muestras de ARN tratadas con la desoxirribonucleasa resultan todas negativas a la amplificación del gen IL2 (ausencia de transcripción), sin embargo cuando se omite la digestión hay amplificación del gen IL2 lo que indica la presencia de cierta cantidad ADN residual (figura 1). En el caso de haber habido transcripción el tamaño de la banda sería inferior ya que el fragmento de ADN genómico amplificado incluye un intrón, aunque, en ensayos previos (resultados no mostrados), este gen no ha manifestado actividad transcripcional en el espermatozoide congelado.

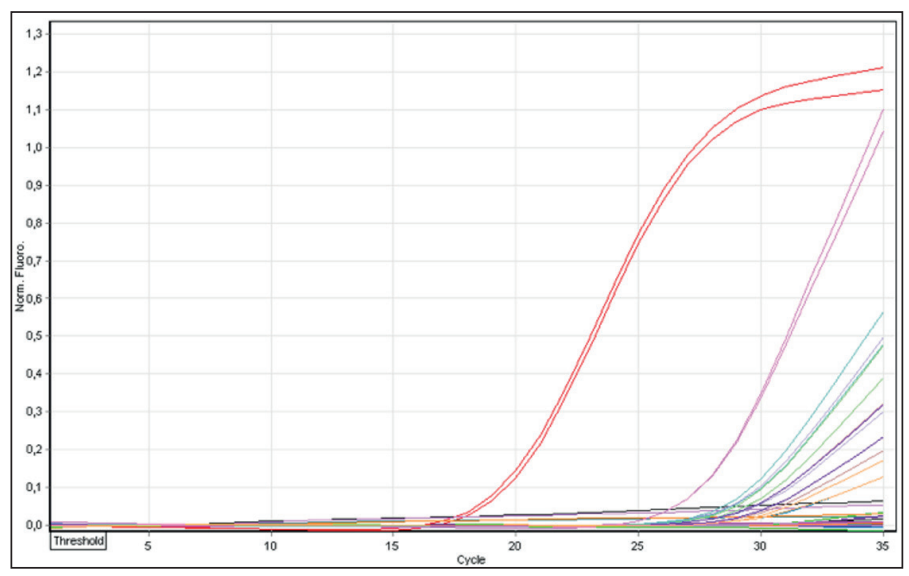

Figura 1. Curvas de amplificación de una secuencia no expresada del gen de la Interleukina 2 en muestras duplicadas de ARN extraído sin digestión del ADN residual y las mismas muestras de ARN después del protocolo de digestión del ADN residual.
De los genes candidatos probados, se obtienen resultados satisfactorios en la amplificación de los genes $A C T B, R P L 32$ y $U B B$ con ciclos de cuantificación $(\mathrm{Cq})$ que oscilan entre 25 y 35 . En las figuras 2 y 3 se representan los resultados obtenidos para el gen $R P L 32$. El análisis de la curva de fusión demuestra la especificidad de la amplificación, ya que aparece un único pico, resultando prácticamente ausente la aparición de dímeros u otros productos inespecíficos que se pudieran formar en la reacción (figura 2). La electroforesis en gel de agarosa indica que el tamaño de las bandas formadas coincide con el tamaño esperado del amplicón (figura 3).

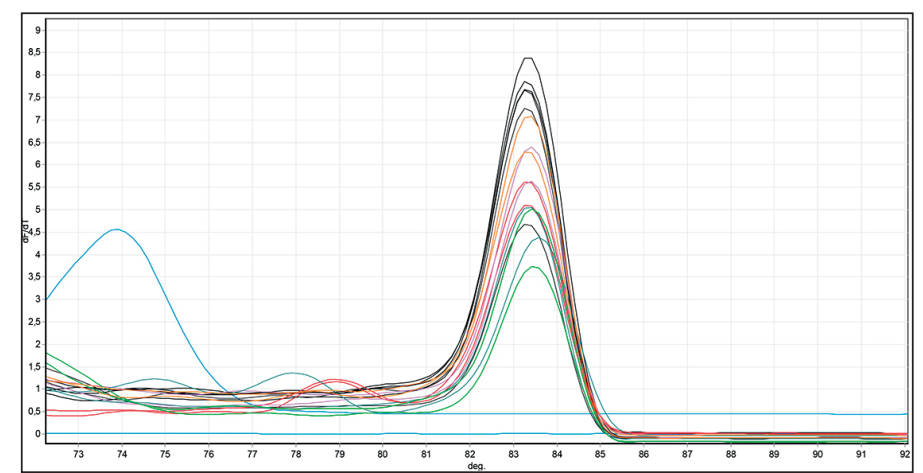

Figura 2. Curvas de fusión de una secuencia de 138 pares de bases $(p b)$ del gen RPL32 amplificadas en muestras duplicadas de ADN, ADNm de leucocitos y ADNm de espermatozoides congelados. Rojo: ADN; Negro: ADNm de leucocitos; Azul: Control sin muestra; Otros colores: ADNc espermatozoides.

Se observa una amplificación buena en los genes GAPDH, $A T P 5 B, H S P 90$ y SDHA, pero aparecen varios picos en el análisis de curvas de fusión que indican la presencia de fragmentos de ADN de diferente tamaño e inespecíficos, por lo que fueron rechazados como posibles genes de referencia en semen congelado equino.

El gen $U B B$ obtiene un Cq promedio superior al RPL32 y $A C T B$ (tabla 2). Los resultados de analizar los datos con 


\section{Selección de genes de referencia en semen equino criopreservado para su uso en estudios de ...}

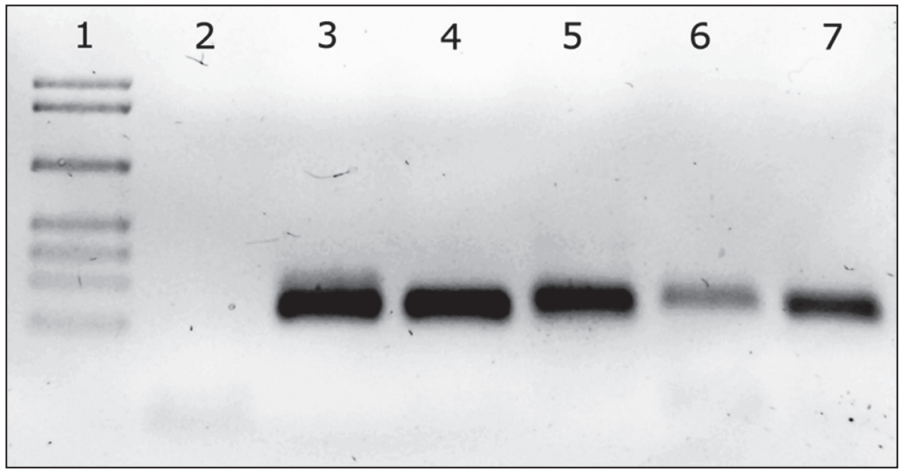

Figura 3. Electroforesis en gel de agarosa al 3\% de los productos de qPCR del gen RPL32 (138 pb). El sentido de la electroforesis es de arriba hacia abajo. Columna 1.- Marcador de pesos molecular (706, 608, 406, 269, 215, 170, 118); Columna 2.- Control sin muestra; Columnas 3 y 4.- ADNm de leucocitos; Columnas 5, 6 y 7.- ADNm de espermatozoides.

el programa de análisis NormFinder indican que la menor variación entre grupos ha sido la del gen $U B B$ seguida por $A C T B$ (tabla 3 ). También se asigna un valor de estabilidad a cada gen siendo de nuevo $U B B$ el que tiene un valor inferior que se asocia a mayor estabilidad. La mejor combinación de genes candidatos es la formada por $U B B$ y $R P L 32$ con un valor de 0,007 .

Tabla 2. Valores medios de ciclos de cuantificación ( $\mathrm{Cq}$ ) calculados por muestra.

\begin{tabular}{|ccc|}
\hline Gen & Cq medio & Desviación estándar \\
\hline$A C T B$ & 32,6 & 0,6 \\
$R P L 32$ & 33,8 & 1,4 \\
UBB & 29,4 & 1,4 \\
\hline
\end{tabular}

Tabla 3. Valores de estabilidad intra y entre grupos para cada uno de los genes candidatos.

\begin{tabular}{|cccccc|}
\hline & \multicolumn{2}{c}{ Dentro de grupos } & \multicolumn{2}{c|}{ Entre grupos } & Estabilidad \\
\hline Gen/Grupo & 1 & 2 & 1 & 2 & \\
$A C T B$ & 0,000 & 0,002 & $-0,002$ & 0,002 & 0,013 \\
RPL32 & 0,001 & 0,000 & 0,014 & $-0,014$ & 0,012 \\
UBB & 0,000 & 0,000 & 0,001 & $-0,001$ & 0,008 \\
\hline
\end{tabular}

Los resultados que ofrece el programa REST 2009 son que ninguno de los genes analizados expresa diferencias entre los grupos (baja y alta fragmentación) excepto el gen $R P L 32$ que aparece significativamente sobreexpresado en el grupo de alta fragmentación (tabla 4).

\section{DISCUSIÓN}

El campo de la expresión génica en semen está más estudiado en medicina humana, se han publicado trabajos en los que usan como genes de referencia el gen $G A P D H^{12,13}, A C T B^{13-15}$, Ciclofilina $A^{13}$, Proteína de choque térmico 1 beta $(H S P C B)$ o $A T P 5 B^{13}$.

En équidos existen varios trabajos en los que se analizan diferentes genes candidatos para el estudio de la expresión génica en determinadas patologías o grupo de células concretas en las que los genes $A C T B, G A P D H, U B B$ y RPL32 son frecuentemente empleados como genes de referencia ${ }^{16-20}$. Por el contrario, hay pocos trabajos sobre expresión génica en semen equino criopreservado. Wrench y col. ${ }^{1}$ (2010) tipifican el ARNm de $A C T B$ y $G A P D H$ para demostrar la inexistencia de ARNm de la proténa $S P 22$, aunque no realizan un estudio de expresión diferencial propiamente dicho.

En el presente trabajo, el gen $G A P D H$ no se ha amplificado correctamente, por lo que se ha descartado a pesar de ser usado en trabajos de expresión en semen fresco ${ }^{1,17-19}$. Sin embargo, otros genes como $A C T B$, la $U B B$ y el RPL32 se han podido amplificar en los todos los casos. Wrench y col. ${ }^{1}$ (2010) realizan un proceso de extracción donde concentran mucho la muestra y las células somáticas no son eliminadas por separación en gradiente, sino que solamente se rompen mediante una solución de lisis específica por lo que podrían quedar restos de ARNm de las células somáticas. Las posibles causas de esta disparidad en la expresión del gen GAPDH podrían ser explicadas porque no se haya podido obtener suficiente ARNm con el método de extracción utilizado, porque haya habido una degradación selectiva del ARNm de este gen atribuible a los dos años de almacenamiento en nitrógeno líquido, o simplemente que los citados autores no hayan podido eliminar las trazas de ARNm procedente de células somáticas mediante la técnica de extracción empleada.

Existen varios métodos disponibles para la normalización precisa de la expresión génica mediante RT-qPCR ${ }^{10,21}$, sin embargo, no hay un consenso generalizado dentro de la comunidad científica sobre qué método sería el más adecuado. Por esa razón, se debe realizar una comparación de diferentes procedimientos de cálculo de selección de genes de referencia, para llevar a cabo una mejor identificación de los genes de referencia más adecuados 228 . Jacob y col. ${ }^{23}$ (2013) recomiendan el uso de más de un gen de referencia, así como también de más de un algoritmo para la evaluación de la estabilidad de la expresión. En el presente trabajo, se comparan dos metodologías (NormFinder y REST 2009) ampliamente usadas ${ }^{24-29}$ para evaluar siete genes de referencia candidatos, con el fin de seleccionar aquellos de mayor estabilidad para estudios de calidad seminal.

Cuando se tratan los genes $A C T B$ y $U B B$ individualmente, ofrecen buenos resultados, sin embargo, cuando se estudian por parejas los resultados han sido poco concluyentes, y difieren se-

Tabla 4. Resultados de expresión relativa de genes candidatos para un valor de $P<0.05$.

\begin{tabular}{|ccccccc|}
\hline Gen & Eficiencia & Expresión & Error estándar & IC 95\% & P(H1) & Resultado \\
\hline$A C T B$ & 0,750 & 1,565 & $0,894-2,896$ & $0,477-3,711$ & 0,063 & \\
$R P L 32$ & 0,786 & 3,011 & $1,416-7,181$ & $0,629-16,515$ & 0,003 & Sobreexpresado \\
$U B B$ & 0,778 & 1,573 & $0,501-6,674$ & $0,292-10,782$ & 0,308 & \\
\hline
\end{tabular}




\section{A. Pérez Rico, et al.}

gún el software utilizado. De esta forma, con el software NormFinder se consideran más estables los genes $U B B$ y $R P L 32$, mientras que con el programa REST 2009 se considera que $R P L 32$ se encuentra sobreexpresado en uno de los sementales.

\section{CONCLUSIÓN}

En estudios de expresión genética en semen criopreservado empleando la técnica de la PCR cuantitativa, pueden usarse los genes $U B B, A C T B$ y RPL32 como genes de referencia. Al agrupar los caballos en función del porcentaje de fragmentación de la cromatina, el gen RPL32 se encontró sobreexpresado, por lo que se pone de manifiesto la necesidad de hacer ensayos de estabilidad de los genes de referencia atendiendo a grupos de individuos afectados y no afectados de una patología o circunstancia de interés, como paso previo de la realización de experimentos de expresión genética.

\section{AGRADECIMIENTOS}

El Organismo Autónomo Cría Caballar de las Fuerzas Armadas ha financiado los análisis de biología molecular. La Diputación de Córdoba ha contribuido prestando sus instalaciones para realizar los análisis genéticos.

El estudio se encuadra dentro de las actividades y objetivos del Convenio de Colaboración que el Organismo Autónomo Cría Caballar de las Fuerzas Armadas tiene suscrito con la Diputación de Córdoba.

\section{BIBLIOGRAFÍA}

1. Wrench N, Pinto CRF, Klinefelter GR, et al. Effect of season on fresh and cryopreserved stallion semen. Anim Reprod Sci. 2010;119(3-4):219-227.

2. Das PJ, Paria N, Gustafson-Seabury A, et al. Total RNA isolation from stallion sperm and testis biopsies. Theriogenology. 2010;74(6):1099-1106, 1106e1-2.

3. Lambard S, Galeraud-Denis I, Martin G, et al. Analysis and significance of mRNA in human ejaculated sperm from normozoospermic donors: relationship to sperm motility and capacitation. Mol Hum Reprod. 2004;10(7):535 -541.

4. Gur Y, Breitbart H. Mammalian sperm translate nuclear-encoded proteins by mitochondrial-type ribosomes. Genes Dev. 2006;20(4):411-416.

5. Samplaski MK, Agarwal A, Sharma R, Sabanegh E. New generation of diagnostic tests for infertility: review of specialized semen tests. Int J Urol. 2010;17(10):839-847.

6. Robinson TL, Sutherland IA, Sutherland J. Validation of candidate bovine reference genes for use with real-time PCR. Ve. Immunol Immunopathol. 2007;115(1-2):160-165.

7. Lee PD, Sladek R, Greenwood CMT, Hudson TJ. Control genes and variability: absence of ubiquitous reference transcripts in diverse mammalian expression studies. Genome Res. 2002;12(2):292-297.

8. Huggett J, Dheda K, Bustin S, Zumla A. Real-time RT-PCR normalisation; strategies and considerations. Genes Immun. 2005;6(4):279-284.

9. Untergasser A, Nijveen H, Rao X, et al. Primer3Plus, an enhanced web interface to Primer3. Nucleic Acids Research. 2007;35(Web Server):W71-W74.

10. Andersen CL, Jensen JL, Ørntoft TF. Normalization of real-time quantitative reverse transcription-PCR data: a model-based variance estimation approach to identify genes suited for normalization, applied to bladder and colon cancer data sets. Cancer Res. 2004;64(15):5245-5250.

11. Pfaffl MW, Horgan GW, Dempfle L. Relative expression software tool (REST) for group-wise comparison and statistical analysis of relative expression results in real-time PCR. Nucleic Acids Res. 2002;30(9):e36.

12. Carreau S, Delalande C, Galeraud-Denis I. Mammalian sperm quality and aromatase expression. Microsc Res Tech. 2009;72(8):552-557.

13. Cavalcanti MCO, Failling K, Schuppe HC, et al. Validation of reference genes in human testis and ejaculate. Andrologia. 2011;43(5):361-367.

14. Lima SB, Cenedeze MA, Bertolla RP, et al. Expression of the HSPA2 gene in ejaculated spermatozoa from adolescents with and without varicocele. Fertil Steril. 2006;86(6):1659-1663

15. Ferlin A, Speltra E, Patassini C, et al. Heat shock protein and heat shock factor expression in sperm: relation to oligozoospermia and varicocele. J Urol. 2010;183(3):1248-1252.

16. Bogaert L, Van Poucke M, De Baere C, et al. Selection of a set of reliable reference genes for quantitative real-time PCR in normal equine skin and in equine sarcoids. BMC Biotechnol. 2006;6:24.

17. Cappelli K, Felicetti M, Capomaccio S, et al. Exercise induced stress in horses: selection of the most stable reference genes for quantitative RT-PCR normalization. BMC Mol. Biol. 2008;9:49.

18. Smits K, Goossens K, Van Soom A, et al. Selection of reference genes for quantitative real-time PCR in equine in vivo and fresh and frozen-thawed in vitro blastocysts. BMC Res Notes. 2009;2:246.

19. Zhang YW, Davis EG, Bai J. Determination of internal control for gene expression studies in equine tissues and cell culture using quantitative RT-PCR. Vet. Immunol Immunopathol. 2009;130(1-2):114-119.

20. Brooks SA, Bailey E. RT $\otimes q P C R$ Comparison of mast cell populations in whole blood from healthy horses and those with laminitis. Anim Genet. 2010;41:16-22.

21. Vandesompele J, De Preter K, Pattyn F, et al. Accurate normalization of realtime quantitative RT-PCR data by geometric averaging of multiple internal control genes. Genome Biol. 2002;3(7):RESEARCH0034.

22. Ayers D, Clements DN, Salway F, Day PJR. Expression stability of commonly used reference genes in canine articular connective tissues. BMC Vet Res. 2007;3:7.

23. Jacob F, Guertler R, Naim S, et al. Careful Selection of Reference Genes Is Required for Reliable Performance of RT-qPCR in Human Normal and Cancer Cell Lines. PLoS One. 2013;8(3). Available at: http://www.ncbi.nlm. nih.gov/pmc/articles/PMC3598660/. Accedido abril 11, 2013.

24. Denkert C, Loibl S, Kronenwett R, et al. RNA-based determination of ESR1 and HER 2 expression and response to neoadjuvant chemotherapy. Ann Oncol. 2013;24(3):632-639.

25. Mays LE, Ammon-Treiber S, Mothes B, et al. Modified Foxp3 mRNA protects against asthma through an IL-10-dependent mechanism. J Clin Invest. 2013;123(3):1216-1228.

26. Macqueen DJ, Serrana DG de la, Johnston IA. Evolution of Ancient Functions in the Vertebrate Insulin-Like Growth Factor System Uncovered by Study of Duplicated Salmonid Fish Genomes. Mol Biol Evol. 2013. Available at: http://mbe.oxfordjournals.org/content/early/2013/02/19/molbev. mst017. Accedido abril 11, 2013.

27. Rehren F, Ritter B, Dittrich-Breiholz O, et al. Induction of a broad spectrum of inflammation-related genes by Coxsackievirus B3 requires Interleukin-1 signaling. Med Microbiol Immunol. 2013;202(1):11-23.

28. Rostrup E, Slettom G, Seifert R, et al. Effect of combined thermal and electrical muscle stimulation on cardiorespiratory fitness and adipose tissue in obese individuals. Eur J Prev Card. 2013. Available at: http:// cpr.sagepub.com/content/early/2013/03/20/2047487313483606. Accedido abril 11, 2013.

29. Spinsanti G, Zannolli R, Panti C, et al. Quantitative Real-Time PCR detection of TRPV1-4 gene expression in human leukocytes from healthy and hyposensitive subjects. Mol Pain. 2008;4(1):51.

30. Beekman L, Tohver T, Dardari R, Léguillette R. Evaluation of suitable reference genes for gene expression studies in bronchoalveolar lavage cells from horses with inflammatory airway disease. BMC Mol Biol. 2011;12:5. 